OPEN ACCESS

Approved by:

Frontiers in Immunology Editorial Office,

Frontiers Media SA, Switzerland

*Correspondence:

Roberta Pelanda

roberta.pelanda@ucdenver.edu

Specialty section

This article was submitted to B Cell Biology

a section of the journal

Frontiers in Immunology

Received: 15 August 2018 Accepted: 06 September 2018 Published: 27 September 2018

Citation:

Greaves SA, Peterson JN, Torres RM and Pelanda $R$ (2018) Corrigendum: Activation of the MEK-ERK Pathway Is

Necessary but Not Sufficient for

Breaking Central B Cell Tolerance.

Front. Immunol. 9:2218.

doi: 10.3389/fimmu.2018.02218

\section{Corrigendum: Activation of the MEK-ERK Pathway Is Necessary but Not Sufficient for Breaking Central B Cell Tolerance}

\author{
Sarah A. Greaves ${ }^{1}$, Jacob N. Peterson ${ }^{1}$, Raul M. Torres ${ }^{1,2}$ and Roberta Pelanda ${ }^{1,2 *}$ \\ ${ }^{1}$ Department of Immunology and Microbiology, University of Colorado School of Medicine, Aurora, CO, United States, \\ ${ }^{2}$ Department of Biomedical Research, National Jewish Health, Denver, CO, United States
}

Keywords: B cells, B cell tolerance, BCR signaling, MAP kinase, ERK, B cell development, autoreactive B cells, mouse models

\section{A Corrigendum on}

Activation of the MEK-ERK Pathway Is Necessary but Not Sufficient for Breaking Central B Cell Tolerance

by Greaves SA, Peterson JN, Torres RM, Pelanda R. Front. Immunol. (2018) 9:707. doi: $10.3389 /$ fimmu.2018.00707

In the original article, a mistake was found in affiliation 1. The state should be CO (Colorado) instead of IL (Illinois). The authors apologize for this error and state that this does not change the scientific conclusions of the article in any way.

The original article has been updated.

Conflict of Interest Statement: The authors declare that the research was conducted in the absence of any commercial or financial relationships that could be construed as a potential conflict of interest.

Copyright $(2018$ Greaves, Peterson, Torres and Pelanda. This is an open-access article distributed under the terms of the Creative Commons Attribution License (CC BY). The use, distribution or reproduction in other forums is permitted, provided the original author(s) and the copyright owner(s) are credited and that the original publication in this journal is cited, in accordance with accepted academic practice. No use, distribution or reproduction is permitted which does not comply with these terms. 